saturation index. This may have been due to impaired metabolism of lipids, substantial regeneration of tissue within the liver, or undetected precancerous lesions, especially in the patient with cirrhosis.

\section{References}

1 Quinn PJ. Models for adaptive changes in cell membranes. Biochem Soc Trans $1983 ; 11: 329-30$

2 Sandeman $\mathrm{H} \mathrm{Jr}$. Regulation of membrane enzymes by lipids. Biochim Biophys

Acta 1979;515:209-37.
3 Apostolov K, Barker W. Cyclic effects of interferon and its antagonist on the saturation of 18-carbon fatty acids. Ann Virol $1984 ; 135: 245-56$.
4 Apostolov K, Barker W. Reversible increase in the saturation of 18-carbon fatty acids induced by diphtheria toxin in tissue culture cells. Infect Immun 1982;38: 843-7.

5 Nozawa CM, Apostolov K. Association of the cytopathic effects of Sindbis virus with increased fatty acid saturation. $\mathcal{F}$ Gen Virol 1982;59:219-22.

6 Nozawa $C M$, Apostolov $\mathrm{K}$. Increase in the saturation of $\mathrm{C} 18$ fatty acids induced by Coxsackie B6 virus in Vero cells. Virology 1982;120:247-50.

7 Apostolov K, Barker W, Catovsky D, Goldman J, Matutes E. Reduction in the stearic to oleic acid ratio in leukaemic cells - a possible chemical marker of

malignancy. Blut (in press).
8 Apostolov K, Barker $W$. The effects of interferon on the fatty acids in uninfected cells. FEBS Lett $1981 ; 126: 261-4$

, Thompson A Barker W Reduction in the . Prev 1984;7:477.

10 Heldin $\mathrm{CH}$, Westermark B. Growth factors: mechanism of action and relation to oncogenes. FEBS Lett $1984 ; 37: 9-20$.

(Accepted 19 April 1985)

\title{
IgM and IgG antibodies to human $T$ cell lymphotropic retrovirus (HTLV-III) in lymphadenopathy syndrome and subjects at risk for AIDS in Italy
}

\author{
F AIUTI, P ROSSI, M C SIRIANNI, M CARBONARI, M POPOVIC, M G SARNGADHARAN, \\ L CONTU, M MORONI, S ROMAGNANI, R C GALLO
}

\begin{abstract}
A study was performed to assess the prevalence of specific antibodies to human $T$ cell lymphotropic retrovirus (HTLV-III) in patients with lymphadenopathy syndrome, patients with the acquired immune deficiency syndrome (AIDS), and those at risk of AIDS. Serum samples were obtained from these groups and from healthy controls in selected cities in Italy, and antibodies to HTLV-UI were measured by immunofluorescence assay and, in a few patients, by Western blotting. In addition, IgM antibody values were measured in 82 of those positive for HTLV-III. Altogether, 235 out of 320 patients with lymphadenopathy syndrome had antibodies to HTLV-III, the proportions being highest in haemophiliacs, homosexuals, and drug addicts from Rome; 11 out of 12 patients with AIDS had antibodies; 78 out of 439 subjects at risk for AIDS had antibodies; and six out of 30 patients with lymphadenopathy syndrome and positive for HTLV-III antibodies and nine of 52 patients at risk of AIDS had a detectable titre of IgM.
\end{abstract}

HTLV-III is widespread in groups at risk of AIDS in

\footnotetext{
Department of Clinical Immunology, Institute of Internal Medicine III, University "La Sapienza," Rome; Institute of Internal Medicine, University of Cagliari; Department of Infectious Diseases, University of Milan; and Department of Clinical Immunology, University of Florence, Italy; and Laboratory of Tumour Cell Biology, National Cancer Institute, Bethesda, MD, USA

F AIUTI, MD, professor

P ROSSI, MD

$M$ C SIRIANNI, MD

$M$ CARBONARI, MD

M POPOVIC, MD, PHD

M G SARNGADHARAN, MD, PHD

L CONTU, MD, professor

M MORONI, MD, professor

S ROMAGNANI, MD, professor

R C GALLO, MD, professor
}

Correspondence and requests for reprints to: Professor F Aiuti, Cattedra Immunologia Clinica, Universita di Roma "La Sapienza," Viale dell'Universita, 37, 00185 Rome, Italy.
Italy, and antibodies to HTLV-III are highly prevalent in patients with lymphadenopathy syndrome. A higher proportion of drug abusers were positive for antibodies than in previous studies. HTLV-III "infection" would appear to be spread mainly in compromised hosts, as none of the controls were positive for antibodies.

\section{Introduction}

Acquired immune deficiency syndrome (AIDS) and lymphadenopathy syndrome, prevalent in homosexuals, drug abusers, and haemophiliacs, are aetiologically related to two retroviruses -namely, lymphadenopathy virus (LAV) ${ }^{1}$ and human $\mathrm{T}$ cell lymphotropic retrovirus (HTLV-III). ${ }^{2}$ In the past two years cases of lymphadenopathy syndrome have increased in Italy, but only 29 cases of AIDS have been recorded. ${ }^{3}$ We report an epidemiological study investigating the prevalence of specific antibodies to HTLV-III in patients with AIDS and lymphadenopathy syndrome and subjects at risk for AIDS in Italy.

\section{Patients and methods}

Serum samples were obtained from patients and healthy subjects in Rome, Milan, Florence, Naples, Cagliari, Verona, Turin, Genoa, Viterbo, and Catanzaro.

Lymphadenopathy syndrome-Criteria for selecting patients with lymphadenopathy syndrome were those established by the CDCNIH working group. In addition to unexplained lymphadenopathy affecting two or more extrainguinal sites and persisting for more than three months all patients had two or more other symptoms, such as fatigue, muscle pain, night sweats, weight loss, and moderate fever. They also had two or more of the following abnormalities: cutaneous anergy, lymphopenia, inversion of the OKT4:T8 ratio, increased immunoglobulin concentrations, and raised antibody titre to cytomegalovirus or Epstein-Barr virus or both. The overall population consisted of 320 patients with lymphadenopathy syndrome, of whom 298 were drug addicts, 16 homosexuals, and six haemophiliacs (see table). In 30 drug abusers and five homosexuals serum samples had also been collected one to two years before, when the patients were symptom free.

AIDS-Serum samples were collected from 12 patients with AIDS.

Subjects at risk for AIDS and lymphadenopathy syndrome (see table)-Serum samples were collected from 70 homosexuals or bi- 
sexuals (who had more than 50 partners a year). Some of these had recurrent venereal infection, syphilis, gonorrhoea, herpes genitalis, and chlamydiosis, and $19(27 \%)$ had hepatitis B infection. None had clinical evidence of AIDS or lymphadenopathy syndrome at the time of sampling. We also selected 259 intravenous heroin abusers for the study. None had lymphadenopathy syndrome, but roughly $35 \%$ of them showed immunological abnormalities. Eighty eight haemophiliacs were also selected. None of these had lymphadenopathy syndrome, but most showed immunological abnormalities. ${ }^{3}$ Twenty two other patients with a history of multiple transfusions were also tested. A total of 660 serum samples were collected from various categories of healthy people (530 male, 80 female, 50 children) homogeneous for sex and age. Adults were aged 18-65 years. Healthy subjects comprised 280 selected from five different blood banks, 45 laboratory and hospital personnel, 140 military servicemen, and 30 relatives of patients with AIDS and lymphadenopathy syndrome. Lastly, 117 serum samples from patients with infectious and miscellaneous diseases (viral diseases, lymphoproliferative disorders, and classical Kaposi's sarcoma) were tested.

Antibodies to HTLV-III were detected by immunofluorescence assay. ${ }^{2}$ Serum samples were incubated with the infected HTLV-III permissive aneuploid cell line $\mathrm{H} 9$ and the cells then counterlabelled with fluorescein isothiocyanate antiserum to IgG and examined for immunofluorescence. The matched, uninfected cell line from the same clone was used as control. Additionally, 50 serum samples from patients with AIDS or lymphadenopathy syndrome were studied by Western blotting. ${ }^{2}$

Measurement of IgM-In 82 patients positive for HTLV-III antibodies (30 patients with lymphadenopathy syndrome, 52 subjects at risk) we used a fluorescence conjugated monoclonal anti- $\mu$ antibody as a second reagent as well as anti-IgM heteroantiserum to measure IgM antibody values.

Antibodies to $H T L V$-III in patients with lymphadenopathy syndrome and subjects at risk for AIDS in various Italian cities

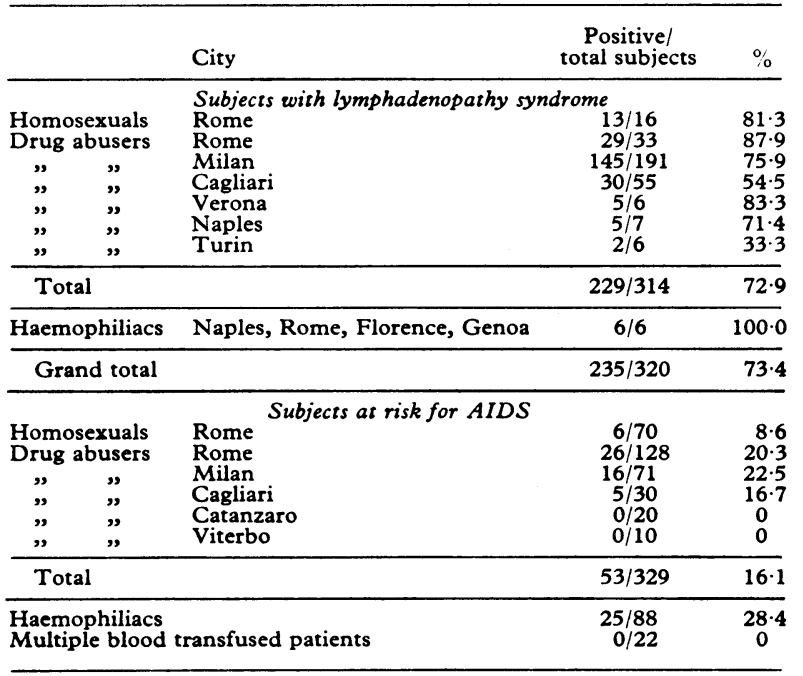

\section{Results}

Patients with lymphadenopathy syndrome-Antibodies against HTLV-III were detected in $235(73.4 \%)$ of the 320 patients with lymphadenopathy syndrome (table). The highest proportions of positive samples were found in haemophiliacs (6/6) and in homosexuals (13/16) and drug addicts (29/33) from Rome. Among the drug addicts 18 were women, of whom 12 (including two prostitutes) were positive for HTLV-III antibodies. Interestingly, antibodies against HTLVIII were not detected in 15 samples (from 10 drug abusers from Milan and five homosexuals from Rome) collected one to two years before, when the patients had been symptom free. All of our patients with lymphadenopathy syndrome showed immunological abnormalities$94 \%$ an inverted OKT $4:$ T 8 ratio and $97 \%$ anergy to skin tests.

Patients with AIDS-Of the 12 patients with AIDS, 10 were positive by immunofluorescence and 11 positive by Western blotting. None of the healthy subjects or those with other disorders were positive.
Presence of IgM-Six out of 30 patients with lymphadenopathy syndrome and positive for HTLV-III antibodies and nine of 52 subjects in the at risk group had a detectable titre of isotypical IgM. In four cases the IgM antibody titre was significantly higher than the IgG titre.

Results of Western blotting were analysed by comparing a series of negative and positive serum samples tested either by immunofluorescence in Rome or by Western blotting in Bethesda. In only one case of lymphadenopathy syndrome in a drug abuser and one case of $\mathbb{E}$ AIDS did Western blotting give a positive result when the result of immunofluorescence was negative. No false positive results occurred with the immunofluorescence test.

\section{Discussion}

In this study the prevalence of antibodies to HTLV-III in groups at risk for AIDS was higher than might be expected from the low incidence of AIDS in the population. We cannot explain this, but the observation supports the hypothesis that HTLV-III infection is widespread in groups at risk for AIDS in Italy. The proportions of patients with lymphadenopathy syndrome who were positive for antibodies varied, possibly due to the fact that serum samples were collected at different stages of the disease and from different geographical areas. Furthermore, that the infection still seems to be absent in small towns may be due to the low diffusion of HTLV-III infection among drug addicts in areas far away from large cities.

Compared with studies in other countries, such as Britain, ${ }^{4} \vec{g}$ we found a higher proportion of apparently healthy intravenous drug abusers who were positive for antibodies. This may also be explained by the difference in spread of infection among geographical areas-see, for example, Milan and Catanzaro (table)compared with Britain.

To our knowledge, all previous studies have been based on the $\vec{\varphi}$ detection of IgG antibodies. ${ }^{1-4}$ We are the first to report that a or significant proportion of cases have IgM antibodies to HTLVIII, suggesting the possibility of recent infection. Furthermore, the overall prevalence of IgM antibodies was similar in patients with lymphadenopathy syndrome and subjects in the at risk group. This latter finding appears to provide evidence for a primary antibody response to a recently acquired HTLV-III infection, as in diseases similar to mononucleosis. ${ }^{5}$

In conclusion, our studies show that despite the small number of cases of AIDS seen in Italy since 1981 there is a high prevalence of antibodies to HTLV-III among patients with lymphadenopathy syndrome. This suggests that HTLV-III may have entered Italy as a result of spread in the United States and, therefore, that we might expect to see more cases of AIDS in Italy. These results support the idea that HTLV-III "infection" is spread mainly in compromised hosts, since none of the controls were positive for the antibodies.

We thank Mrs A H Constantine for editorial help. This work has been supported in part by grants from the University of Rome of $60 \%$ (1983), the National Council for Research (Consiglio Nazionale $D$ delle Ricerche) (Immunodeficienze) (1984), and the Ministry of Education (Ministero Pubblica Istruzione), University of Rome (1983-4).

\section{References}

1 Barré-Sinoussi F, Chermann C, Rey F, et al. Isolation of a T-lymphotropic retrovirus from a patient at risk for acquired immune deficiency syndrome (AIDS). Science 1983;220:869-7

2 Gallo RC, Salahuddin SZ, Popovic M, et al. Frequent detection and isolation of cytopathic retroviruses (HTLV-III) from patients with AIDS and at risk for AIDS. Science 1984;224:500-3.

3 Rossi P, Sirianni MC, Contu L, et al. Antibodies to human T-lymphotropic retrovirus HTLV-III in patients with lymphoadenopathy syndrome and in individuals at risk for AIDS in Italy. Immunologia Clinica Sperimentale 1984;4: 295-304

4 Cheingsong-Popov R, Weiss RA, Dagleish A, et al. Prevalence of antibody to human T-lymphotropic virus type III in AIDS and AIDS-risk patients in Britain. Lancet 1984;ii:477-80

Cooper DA, Gold J, Maclean P, et al. Acute AIDS retrovirus infection. Lancet $1985 ; i: 537-9$.

(Accepted 28 March 1985)

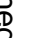

